\title{
PERBEDAAN PEMAHAMAN KONSEP MATEMATIKA ANTARA SISWA YANG BELAJAR DENGAN MENGGUNAKAN MODEL PEMBELAJARAN KOOPERATIF TIPE JIGSAW DAN KONVENSIONAL
}

\author{
Siti Hadijah ${ }^{1)}$, Sutji Rochaminah ${ }^{2)}$, Maxinus Jaeng ${ }^{3)}$ \\ syty_sykh@yahoo.com ${ }^{1}$, suci_palu@yahoo.co.id ${ }^{2)}$, maxjaeng@yahoo.com ${ }^{3)}$
}

\begin{abstract}
Abstrak: Penelitian ini bertujuan untuk mengetahui apakah pemahaman konsep matematika siswa yang belajar dengan menggunakan model pembelajaran kooperatif tipe jigsaw lebih baik daripada pemahaman konsep matematika siswa yang belajar dengan menggunakan model pembelajaran konvensional di Kelas IX MTs Negeri 1 Kota Palu. Hipotesis penelitian ini adalah pemahaman konsep matematika siswa yang belajar dengan menggunakan model pembelajaran kooperatif tipe jigsaw lebih baik daripada pemahaman konsep matematika siswa yang belajar dengan menggunakan pembelajaran konvensional. Jenis penelitian ini adalah eksperimen semu. Desain penelitian ini adalah pre-post test control design. Populasi penelitian ini adalah seluruh siswa kelas IX MTs Negeri 1 Kota Palu dengan teknik pengambilan sampel cluster random sampling. Nilai rata-rata siswa kelas eksperimen 47 dan standar deviasi 17,04 sedangkan nilai rata-rata siswa kelas kontrol 40 dan standar deviasi 13,40. Data yang diperoleh berdistribusi normal dan homogen, maka pengujian hipotesis menggunakan teknis statistik parametris yaitu uji t. Hasil pengujian hipotesis diperoleh bahwa nilai $t_{\text {tabel }}=1,67$ dan $t_{\text {hitung }}=2,96$ sehingga $\mathrm{H}_{1}$ diterima dan $\mathrm{H}_{0}$ ditolak. Hal ini menunjukkan bahwa pemahaman konsep matematika siswa yang belajar dengan menggunakan model pembelajaran kooperatif tipe jigsaw lebih baik daripada pemahaman konsep matematika siswa yang belajar dengan menggunakan model pembelajaran konvensional di kelas IX MTsN 1 Kota Palu.
\end{abstract}

Kata Kunci: Model Pembelajaran Kooperatif Tipe Jigsaw, Model Pembelajaran Konvensional, dan Pemahaman Konsep

\begin{abstract}
This research purposed to determine is mathematics concept understanding students who learn by using jigsaw cooperative learning model better than students who learn by using conventional learning model in class IX MTs Negeri 1 Kota Palu. The hypothesis is that mathematics concept understanding students who learn by using jigsaw cooperative learning model better than students who learn by using conventional learning model. The type of research is a quasi experiment. Design of research is pre-post control design. The population of this research is all students of class IX MTs Negeri 1 Kota Palu with samples taken by cluster random sampling technique. The average score of the experiment class students is 47 and standard deviation is 17.04 and the average score of the control class students is 40 and standard deviation is 13.40. The data is normal distribution and homogen, hypothesis test using t test. Results of hypothesis test obtained value $t_{\text {table }}=1.67$ and $t_{\text {count }}=2.96$ it means $H_{1}$ is accepted and $H_{0}$ is rejected. This indicated that mathematics concept understanding students who learn by using jigsaw cooperative learning model have better than mathematics concept understanding students who learn by using conventional learning model in class IX MTsN 1 Kota Palu.
\end{abstract}

Keywords: Jigsaw Cooperative Learning Model, Conventional Learning Model, and Concept Understanding

Matematika merupakan bidang ilmu yang memiliki kedudukan penting dalam pengembangan dunia pendidikan dan merupakan pengetahuan universal yang mendasari perkembangan teknologi modern, serta mempunyai peranan penting dalam kehidupan sehari-hari. Oleh sebab itu, matapelajaran matematika perlu diajarkan kepada semua peserta didik mulai dari sekolah dasar hingga ke jenjang perguruan tinggi untuk membekali peserta didik dengan kemampuan berfikir logis, analitis, sistematis, kritis, kreatis, cermat dan konsisten serta kemampuan bekerja sama (Depdiknas, 2006). 
Konsep dalam matematika adalah suatu ide abstrak yang memungkinkan seseorang dapat mengklafikasikan suatu objek atau kejadian (Hudojo, 2003). Matapelajaran matematika adalah suatu pelajaran yang berhubungan dengan banyak konsep. Konsepkonsep dalam matematika memiliki keterkaitan antara satu dengan yang lainnya, maka siswa harus lebih banyak diberikan kesempatan untuk melihat kaitan-kaitan dengan materi yang lain. Hal tersebut dimaksudkan agar siswa dapat memahami materi matematika secara mendalam. Misalnya jika siswa ingin memahami konsep fungsi kuadrat maka terlebih dahulu dia harus mampu memahami konsep persamaan kuadrat. Demikian juga jika siswa ingin memahami konsep persamaan kuadrat maka terlebih dahulu harus memahami konsep operasi bentuk aljabar.

Pentingnya pemahaman konsep matematika tercantum dalam tujuan pertama pembelajaran matematika menurut Depdiknas (2006) ialah memahami konsep matematika, menjelaskan keterkaitan antara konsep dan mengaplikasikan konsep atau algoritma secara luwes, akurat, efisien, dan tepat dalam pemecahan masalah. Matapelajaran matematika bertujuan agar peserta didik memiliki kemampuan pemahaman konsep dalam memecahkan permasalahan. Menurut NCTM (2000), kemampuan memahami suatu konsep sangat penting karena belajar dengan pemahaman membuat pembelajaran selanjutnya lebih mudah dipahami. Jadi, dapat dikatakan bahwa pemahaman konsep merupakan bagian yang paling penting dalam pembelajaran matematika.

Pemahaman konsep matematika perlu ditanamkan kepada peserta didik sejak dini yaitu sejak anak tersebut masih di sekolah dasar hingga sekolah menengah atas. Peserta didik dituntut mengerti tentang definisi, pengertian, cara pemecahan masalah maupun pengoperasian matematika secara benar, karena hal tersebut akan menjadi bekal dalam mempelajari matematika pada jenjang pendidikan perguran tinggi (Herawati, 2010).

Guru sebagai pendidik memiliki peran penting terhadap keberhasilan pembelajaran siswa. Menurut Slameto (2010) pembelajaran matematika sangat ditentukan oleh strategi dan pendekatan yang digunakan guru dalam mengajar matematika. Penerapan model pembelajaran yang kurang baik akan mempengaruhi pemahaman konsep matematika siswa sehingga model pembelajaran yang digunakan oleh guru harus tepat, efektif, dan efisien. Oleh karena itu, pada saat pembelajaran matematika berlangsung seorang guru dituntut tampil optimal baik dalam menyiapkan rencana pembelajaran maupun pelaksanaan pembelajaran. Selain itu, aktifitas pembelajaran diusahakan selalu melibatkan siswa secara aktif, mengembangkan interaksi multiarah siswa ke guru, guru ke siswa, siswa ke bahan ajar dan siswa ke siswa baik secara personal maupun kelompok, agar pembelajaran bermakna (Nurhikmah, 2015).

Model pembelajaran telah banyak dikembangkan untuk meningkatkan pemahaman konsep siswa serta keterlibatan aktif siswa dalam proses pembelajaran. Satu di antara model pembelajaran kooperatif yang dikembangkan untuk menciptakan suasana belajar yang aktif yaitu model pembelajaran kooperatif tipe jigsaw. Menurut Hamdani (2011) kooperatif jigsaw didesain untuk meningkatkan rasa tanggung jawab siswa terhadap pembelajarannya sendiri dan juga pembelajaran orang lain. Siswa terlibat aktif dalam proses pembelajaran, siswa bukan hanya mempelajari materi yang diberikan tetapi harus mengajarkan materi tersebut ke teman lainnya. Dalam pembelajaran kooperatif tipe jigsaw, siswa lebih mudah menemukan dan memahami konsep-konsep yang sulit ketika mereka saling mendiskusikan masalah-masalah tersebut dengan temannya. Model pembelajaran kooperatif tipe jigsaw dapat meningkatkan hasil belajar matematika siswa. Hal tersebut diketahui dari penelitan-penelitian terdahulu tentang model pembelajaran kooperatif tipe jigsaw. Satu diantaranya yaitu hasil penelitian yang dilakukan Imayati (2013) diperoleh kesimpulan bahwa kemampuan pemahaman konsep 
matematika siswa yang belajar menggunakan model pembelajaran kooperatif tipe jigsaw lebih baik daripada siswa yang belajar menggunakan model pembelajaran konvensional.

Namun, model pembelajaran yang masih saja diterapkan guru di sekolah yaitu model pembelajaran konvensional. Menurut Sanjaya (2006) pada pembelajaran konvensional siswa ditempatkan sebagai penerima informasi secara pasif. Sedangkan, guru lebih banyak aktif dan dianggap sebagai sumber ilmu yang mempunyai peranan sangat penting di dalam kelas. Hasil penelitian yang dilakukan Indrawan (2010) menunjukkan bahwa prestasi belajar matematika dengan menggunakan pembelajaran konvensional mendapatkan hasil yang agak baik dan pembelajaran kooperatif tipe jigsaw mendapatkan hasil yang cukup baik. Sehingga, dicurigai bahwa penelitian tentang pembelajaran jigsaw tersebut dapat meningkatkan pemahaman konsep matematika siswa. Dari hasil penelitian dan penjelasan tersebut, perlu adanya penelitian yang menguji perbedaan pemahaman konsep matematika antara model pembelajaran kooperatif tipe jigsaw dan konvensional di MTsN 1 Kota Palu.

Berdasarkan latar belakang di atas, maka peneliti tertarik untuk melakukan penelitian tentang perbedaan pemahaman konsep matematika antara siswa yang belajar dengan menggunakan model pembelajaran kooperatif tipe jigsaw dan konvensional di kelas IX MTsN 1 Kota Palu. Rumusan masalah penelitian ini adalah apakah pemahaman konsep matematika siswa yang belajar dengan menggunakan model pembelajaran kooperatif tipe jigsaw lebih baik daripada pemahaman konsep matematika siswa yang belajar dengan menggunakan model pembelajaran konvensional di Kelas IX MTs Negeri 1 Kota Palu?

\section{METODE PENELITIAN}

Penelitian ini merupakan penelitian kuantitatif eksperimen. Rancangan penelitian ini adalah eksperimen quasi. Desain penelitian ini pretest-posttest control group design. Populasi penelitian ini seluruh siswa kelas IX MTs Negeri 1 Kota Palu tahun pelajaran 2016/2017, sampel diambil dengan teknik cluster random sampling. Siswa kelas IX H sebagai kelas eksperimen sebanyak 31 orang dan siswa kelas IX G sebagai kelas kontrol sebanyak 30 orang. Pemberian tes dilakukan dua kali yaitu tes awal dan tes akhir dengan soal yang sama tetapi jumlah soal yang berbeda. Tes disusun dalam bentuk soal uraian.

Instrumen penelitian ini adalah tes pemahaman konsep pada materi persamaan kuadrat. Sebelum digunakan, instrumen penelitian tersebut dilakukan dua tahap penilaian yakni penilaian ahli dan uji coba. Penilaian ahli dilakukan untuk memvalidasi isi instrumen tes pemahaman konsep. Uji coba dilakukan untuk mengetahui validitas, reliabilitas, uji daya pembeda dan tingkat kesukaran instrumen penelitian.

Cara menghitung koefisien validitas yaitu menggunakan korelasi Product-Moment dengan taraf signifikan 5\% dan derajat kebebasan $\mathrm{n}-2$. Cara menentukan kriteria koefisien korelasi dapat membandingkan $\mathrm{r}$ hitung dengan tabel $\mathrm{r}$ product moment. Setelah diperoleh harga $r_{x y}$, dilakukan pengujian validitas dengan membandingkan harga $r_{\text {tabel }}$ product moment pada taraf signifikansi $\alpha=5 \%$. Kriteria pengujiannya yaitu jika $\mathrm{r}_{x y} \leq \mathrm{r}_{\text {tabel }}$ maka butir soal tidak valid dan jika $r_{x y}>r_{\text {tabel }}$ maka butir soal valid (Sugiyono, 2010). Rumus yang digunakan untuk mencari koefisien reliabilitas instrumen tes adalah rumus Alpha dengan klasifikasi reliabilitas (Arikunto, 2012) yaitu 0,80 $<r_{11} \leq 1,00$ sangat tinggi, $0,60<r_{11} \leq 0,80$ tinggi, $0,40<r_{11} \leq$ 0,60 sedang, $0,20<r_{11} \leq 0.40$ rendah, dan $r_{11} \leq 0,20$ sangat rendah. Indeks yang digunakan dalam membedakan antara peserta tes yang berkemampuan tinggi dengan peserta yang berkemampuan rendah adalah indeks daya pembeda (Mulyasa, 2009). Perhitungan daya pembeda pada penelitian ini adalah daya pembeda untuk tes uraian. Klasifikasi daya pembeda (Arikunto, 2012) yaitu $0,70<\mathrm{DP} \leq 1,00$ sangat baik, $0,40<\mathrm{DP} \leq 0,70$ baik, $0,20<\mathrm{DP} \leq 0,40$ 
cukup, $0,00<\mathrm{DP} \leq 0,20$ jele). Cara menentukan tingkat kesukaran adalah proporsi menjawab benar. Proporsi menjawab benar yaitu jumlah peserta tes yang menjawab benar pada butir soal yang dianalisis dibandingkan dengan jumlah peserta tes seluruhnya (Mulyasa, 2009). Klasifikasi tingkat kesukaran (Arikunto, 2012) yaitu $0,00<p \leq 0,30$ sukar, $0,30<p \leq 0,70$ sedang dan $0,70<p<1,00$ mudah.

Instrumen pemahaman konsep terdiri dari 4 indikator pemahaman konsep dan 9 butir soal uraian. Instrumen telah divalidasi ahli serta diujicobakan di SMP Negeri 1 Palu. Data yang diperoleh dianalisis validitas, reliabilitas, daya pembeda, dan tingkat kesukarannya. Hasil rekapitulasi analisis uji coba instrumen menunjukkan bahwa 1) validitas butir soal nomor 1a, 1b, 5, dan 9 merupakan soal yang tidak valid sedangkan butir soal nomor 1c, 2a, 2b, 3a, 3b, 4a,4b, 4c, 6, dan 7 merupakan soal yang valid, 2) reliabilitas untuk keseluruhan butir soal mempunyai reliabilitas tinggi, 3) uji daya pembeda butir soal nomor 1a, 1b, 5, 9 mempunyai kriteria daya pembeda yang jelek sedangkan butir soal nomor 1c, 2a, 2b, 3a, 3b, 4a, 4b, 4c, 6, dan 7 mempunyai kriteria daya pembeda yang cukup, dan 4) tingkat kesukaran butir soal nomor 1a, 1b, 4a, 4b termasuk kategori mudah, butir soal nomor 1c, 2a, 2b, 3a, 4c, 5, 6 termasuk kategori sedang, dan butir soal nomor 3b, 7, 8, dan 9 termasuk kategori sukar. Jadi, soal yang digunakan pada penelitian ini sebanyak 7 butir soal uraian.

Teknik analisis data penelitian ini menggunakan uji normalitas, uji homogenitas, dan uji hipotesis. Uji normalitas bertujuan untuk menguji kenormalan data. Pengujian normalitas menggunakan rumus chi square (Sudjana, 2002). Cara mencari $\chi_{\text {tabel }}^{2}$ dengan derajat bebas $=\mathrm{k}-3, \mathrm{k}$ banyaknya kelas dan taraf kepercayaan 95\% atau taraf signifikan $\alpha$ $=5 \%$. Kriteria pengujian, jika $\chi_{\text {hitug }}^{2} \leq \chi_{\text {tabel }}^{2}$, maka data sampel berasal dari populasi yang berdistribusi normal dan jika $\chi_{\text {hitug }}^{2}>\chi_{\text {tabel }}^{2}$, maka data sampel tidak berasal dari populasi yang berdistribusi normal. Rumus untuk menetukan uji homogenitas adalah uji Fisher. Selanjutnya, membandingkan nilai $F_{\text {hitung }}$ dengan nilai $F_{\text {tabel }}$ dengan dk pembilang $\left(n_{1}-1\right)$, dan dk penyebut $\left(n_{2}-1\right)$ dengan taraf signifikasi sebesar $5 \%$ dengan kriteria pengujian yaitu jika $F_{\text {hitung }}>F_{\text {tabel }}$ berarti varians tidak homogen dan jika $F_{\text {hitung }} \leq$ $F_{\text {tabel }}$ berarti varians homogen (Sugiyono, 2010).

Hipotesis penelitian ini adalah $\mathrm{H}_{0}: \mu_{1} \leq \mu_{2}$, pemahaman konsep matematika siswa yang belajar dengan menggunakan model pembelajaran kooperatif tipe jigsaw kurang baik atau sama dengan pemahaman konsep matematika siswa yang belajar dengan menggunakan pembelajaran konvensional. $\mathrm{H}_{1}: \mu_{1}>\mu_{2}$, pemahaman konsep matematika siswa yang belajar dengan menggunakan model pembelajaran kooperatif tipe jigsaw lebih baik daripada pemahaman konsep matematika siswa yang belajar dengan menggunakan pembelajaran konvensional.

Uji hipotesis menggunakan uji perbedaan dua rata-rata yaitu uji satu pihak. Jika $\sigma_{1}=$ $\sigma_{2}$, maka statistik yang digunakan ialah uji t (Sudjana, 2002). Kriteria pengujian yang berlaku ialah jika $t<t_{1-\alpha}$, maka $\mathrm{H}_{0}$ diterima dan $\mathrm{H}_{1}$ ditolak dan jika $t \geq t_{1-\alpha}$, maka $\mathrm{H}_{0}$ ditolak dan $\mathrm{H}_{1}$ diterima. Derajat kebebasan untuk daftar distribusi $\mathrm{t}$ ialah $\left(\mathrm{n}_{1}+\mathrm{n}_{2}-2\right)$ dengan peluang $(1-\alpha)$. Jika $\sigma_{1} \neq \sigma_{2}$, maka statistik yang digunakan adalah uji t' (Sudjana, 2002). Peluang untuk penggunaan daftar distribusi t ialah $(1-\alpha)$ sedangkan dk-nya masing-masing $\left(n_{1}-1\right)$ dan $\left(n_{2}-1\right)$.

\section{HASIL PENELITIAN}

Hasil penelitian yang diperoleh yaitu pemberian tes awal, penerapan model pembelajaran, dan pemberian tes akhir pemahaman konsep pada materi persamaan kuadrat. Tes awal 
pemahaman konsep sebanyak 4 butir soal dan tes akhir pemahaman konsep sebanyak 7 butir soal uraian.

Tabel 1. Perbandingan Statistik Deskriptif Kelas Kontrol dan Eksperimen

\begin{tabular}{ccc}
\hline Aspek & $\begin{array}{c}\text { Kelas } \\
\text { ekperimen }\end{array}$ & Kelas kontrol \\
\hline Jumlah siswa(n) & 31 & 30 \\
Skor rata-rata & 47 & 40 \\
Standar deviasi & 17,04 & 13,40 \\
Nilai tertinggi & 82 & 89 \\
Nilai terendah & 16 & 14 \\
\hline
\end{tabular}

Tabel 2. Hasil Uji Normalitas Data Melalui Uji Chi Kuadrat

\begin{tabular}{ccc}
\hline Aspek & $\begin{array}{c}\text { Kelas } \\
\text { Eksperimen }\end{array}$ & $\begin{array}{c}\text { Kelas } \\
\text { Kontrol }\end{array}$ \\
\hline $\begin{array}{c}\text { Taraf } \\
\text { Signifikan }\end{array}$ & 0,05 & 0,05 \\
Nilai $\chi_{\text {hitung }}^{2}$ & 3,638 & 6,916 \\
Nilai $\chi_{\text {tabel }}^{2}$ & 7,81 & 7,81 \\
\hline
\end{tabular}

Berdasarkan pada Tabel 1 diperoleh informasi bahwa nilai rata-rata kelas eksperimen yaitu 47 lebih tinggi dibandingkan nilai rata-rata kelas kontrol yaitu 40. Secara deskriptif, hal ini menunjukkan bahwa pemahaman konsep matematika siswa kelas eksperimen lebih baik daripada pemahaman konsep matematika kelas kontrol.

Sedangkan pada Tabel 2 dapat dilihat bahwa nilai $\chi_{\text {hitung }}^{2}$ pada kelas eksperimen yaitu

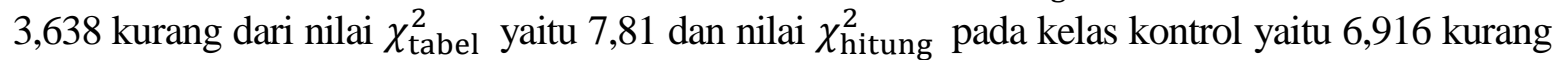
dari nilai $\chi_{\text {tabel }}^{2}$ yaitu 7,81 dengan taraf signifikansi $5 \%$ dan derajat kebebasan $\mathrm{dk}=6-3=3$. Sehingga dapat disimpulkan bahwa pemahaman konsep pada kelas eksperimen dan kelas kontrol berdistribusi normal. Cara mengetahui homogenitas kedua kelas yang diambil sebagai sampel menggunakan uji $\mathrm{F}$ yaitu hasil bagi antara variansi terbesar dan variansi terkecil. Diperoleh dari hasil perhitungan $F_{\text {hitung }}=1,615$ dan berdasarkan tabel distribusi $\mathrm{F}$ dengan taraf signifikansi $\alpha=$ $5 \%$, dk pembilang $\left(n_{1}-1\right)=31-1=30$, dan dk penyebut $\left(n_{2}-1\right)=30-1=29$ diperoleh harga $F_{\text {tabel }}=1,85$. Oleh karena $F_{\text {hitung }}<1,85$ maka $\mathrm{H}_{0}$ diterima artinya pemahaman konsep kelas eksperimen dan kelas kontrol memiliki varians yang sama atau homogen.

Hasil perhitungan uji normalitas dan homogenitas menunjukkan bahwa pemahaman konsep pada kelas eksperimen dan kelas kontrol berdistribusi normal dan homogen. Oleh karena itu, statistik yang digunakan pada uji hipotesis ini adalah statistik parametris teknik uji t. Berdasarkan tabel distribusi $\mathrm{t}$ dengan taraf signifikansi 5\% dan derajat kebebasan 59 diperoleh $t_{\text {tabel }}=1,67109$. Rata-rata hasil tes pemahaman konsep matematika siswa pada kelas eksperimen dikatakan lebih baik daripada kelas kontrol adalah ketika $\mathrm{H}_{0}$ ditolak atau $t_{\text {hitung }} \geq$ $t_{\text {tabel }}$. Hasil perhitungan yang telah dilakukan diperoleh nilai $t_{\text {hitung }}=2,96657$. Hal ini menunjukkan bahwa $\mathrm{H}_{0}$ ditolak karena 2,96657>1,67109 artinya pemahaman konsep matematika siswa di kelas eksperimen lebih baik dari pemahaman konsep matematika di kelas kontrol. Jadi dapat disimpulkan bahwa pemahaman konsep matematika siswa yang belajar dengan menggunakan model pembelajaran kooperatif tipe jigsaw lebih baik dari pemahaman konsep matematika siswa yang belajar dengan menggunakan pembelajaran konvensional.

\section{PEMBAHASAN}

Pelaksanaan proses pembelajaran di kelas eksperimen dengan menerapkan model pembelajaran kooperatif tipe jigsaw siswa dikelompokkan menjadi 6 kelompok asal. Tiap kelompok asal terdiri atas siswa yang berkemampuan tinggi, sedang, dan rendah. Jumlah siswa setiap kelompoknya terdiri atas 5-6 siswa, agar kerjasama antar siswa dapat maksimal. Hal ini sesuai pendapat Isjoni (2010) jumlah siswa yang bekerjasama dalam tiap kelompok harus dibatasi, dikarenakan kelompok-kelompok yang terbentuk dapat bekerjasama secara efektif. 
Setelah kelompok terbentuk, guru membagikan LKS dan masing-masing anggota kelompok mengerjakan satu tugas.

Siswa dari masing-masing kelompok yang memiliki tugas yang sama bertemu dan berkumpul membentuk kelompok yaitu kelompok ahli kemudian siswa berdiskusi. Pembentukan kelompok ahli bertujuan agar siswa saling bekerjasama dan aktif dalam berdiskusi untuk menyelesaikan tugas yang diberikan oleh guru. Hal ini sesuai dengan pendapat Hamdani (2011) melalui diskusi akan terjadi elaborasi kognitif yang baik sehingga dapat meningkatkan keterlibatan aktif siswa dalam pembelajaran, serta memberikan kesempatan kepada siswa untuk mengungkapkan pendapatnya. Selain itu pada saat berdiskusi pada kelompok ahli, siswa saling bertukar informasi dan menghubungkan materi yang baru dipelajari dengan materi yang telah diketahui sebelumnya. Ausubel (2000) mengatakan jika siswa berusaha menguasai informasi baru dengan jalan menghubungkan dengan pengetahuan yang telah diketahuinya maka terjadilah belajar bermakna.

Setiap siswa pada kelompok ahli kembali pada kelompok asal dan masing-masing siswa bertugas mengajarkan hasil diskusi yang diperoleh ke teman sekelompoknya. Hal ini bertujuan agar siswa mempunyai rasa bertanggung jawab. Sesuai pendapat Hamdani (2011) jigsaw didesain untuk meningkatkan rasa tanggung jawab siswa terhadap pembelajarannya sendiri dan juga pembelajaran orang lain. Selain itu, siswa dituntut memiliki saling ketergantungan yang positif terhadap teman sekelompoknya. Siswa tidak hanya mempelajari materi yang diberikan, tetapi mereka juga harus siap memberikan dan mengajarkan materi tersebut kepada anggota lain. Setelah siswa berada pada kelompok asal dan mendiskusikan jawaban yang mereka peroleh dari kelompok ahli, kemudian beberapa kelompok asal dimintai guru untuk mempresentasikan jawaban yang telah diperoleh. Saat berada di proses ini siswa menyamakan pengetahuan yang mereka dapatkan dari hasil diskusi. Sesuai dengan teori belajar Vygotsky (1978) seseorang belajar melalui interaksi dengan orang dewasa dan teman sebaya yang lebih mampu. Interaksi sosial ini memacu terbentuknya ide baru dan memperkaya perkembangan intelektual anak.

Penerapan model pembelajaran kooperatif tipe jigsaw dapat memudahkan siswa menemukan dan memahami konsep-konsep yang sulit ketika siswa saling mendiskusikan masalah-masalah tersebut dengan temannya. Pemahaman konsep matematika siswa menjadi lebih baik dengan menerapkan model pembelajaran kooperatif tipe jigsaw dalam menyelesaikan masalah matematika. Hal ini sesuai dengan hasil penelitian yang dilakukan Rosyidah (2016) bahwa pembelajaran matematika dengan menggunakan model pembelajaran kooperatif tipe jigsaw memberikan pengaruh positif terhadap hasil belajar. Demikian juga dengan hasil penelitian yang dilakukan Imayati (2013) bahwa kemampuan pemahaman konsep matematika siswa yang belajar menggunakan model pembelajaran kooperatif tipe jigsaw lebih baik dari siswa yang belajar menggunakan model pembelajaran konvensional.

Berbeda saat penerapan model pembelajaran konvensional pada kelas kontrol. Penerapan pembelajaran konvensional, guru hanya memberikan penjelasan materi persamaan kuadrat dengan metode ceramah. Kegiatan pembelajaran dimulai dari guru menyampaikan materi, siswa mencatat, bertanya, dan diakhiri dengan pemberian tugas. Hal ini sesuai pendapat Isjoni (2010) dalam model pembelajaran konvensional guru menjadi pusat semua kegiatan pembelajaran di dalam kelas. Pada saat menerapkan model pembelajaran konvensional, keaktifan siswa sangat kurang. Siswa cenderung bosan dan kurang perhatian dalam mengikuti pembelajaran. Akibatnya, pada saat diberikan tes diakhir pertemuan nilai rata-rata pemahaman konsep kelas kontrol lebih rendah dibanding kelas eksperimen. Sesuai dengan hasil penelitian yang dilakukan Indrawan (2010) menyimpulkan bahwa prestasi belajar matematika siswa dengan menggunakan pembelajaran konvensional mendapatkan hasil yang agak baik dibandingkan dengan menggunakan pembelajaran kooperatif jigsaw mendapatkan hasil yang cukup baik. 
Hasil penelitian menunjukkan bahwa perhitungan nilai rata-rata kelas eksperimen 47 dengan standar deviasi 17,04 dan nilai rata-rata siswa kelas kontrol 40 dengan standar deviasi 13,40 . Terdapat perbedaan antara nilai rata-rata kedua kelas yaitu nilai rata-rata pemahaman konsep matematika kelas eksperimen lebih tinggi dibandingkan kelas kontrol dengan selisih sebesar 7. Namun nilai rata-rata pemahaman konsep kedua kelas tersebut jelas tidak mencapai nilai ketuntasan kriteria minimal yaitu 76.

Hasil tes pemahaman konsep matematika siswa yang diperoleh dari kedua kelas sampel diuji prasyarat yang terdiri dari uji normalitas dan homogenitas varians, selanjutnya dilakukan uji hipotesis dengan menggunakan uji-t satu pihak atau pihak kanan. Berdasarkan perhitungan hipotesis diperoleh nilai $t_{\text {hitung }}=2,96$ dan nilai $t_{\text {tabel }}=1,67$ dengan kriteria penerimaan $\mathrm{H}_{1}$ jika $t_{\text {hitung }}>t_{\text {tabel }}$ atau penolakan $\mathrm{H}_{1}$ jika $t_{\text {hitung }} \leq t_{\text {tabel }}$. Ternyata, $t_{\text {hitung }}>t_{\text {tabel }}$ yaitu $2,96>1,67$ berarti pemahaman konsep matematika di kelas eksperimen lebih baik daripada kelas kontrol.

Berdasarkan pengujian hipotesis dapat disimpulkan bahwa pemahaman konsep matematika siswa yang belajar dengan menggunakan model pembelajaran kooperatif tipe jigsaw lebih baik daripada pemahaman konsep matematika siswa yang belajar dengan menggunakan model pembelajaran konvensional di kelas IX MTs Negeri 1 Kota Palu.

\section{KESIMPULAN}

Kesimpulan penilitian ini adalah terdapat perbedaan pemahaman konsep matematika siswa yang belajar dengan menggunakan model pembelajaran kooperatif tipe jigsaw lebih baik daripada pemahaman konsep matematika siswa yang belajar dengan menggunakan model pembelajaran konvensional di kelas IX MTs Negeri 1 Kota Palu.

\section{SARAN}

Saran yang diajukan yaitu diharapkan dalam proses pembelajaran matematika guru dapat menggunakan model-model pembelajaran yang bervariasi sesuai dengan karakteristik materi yang akan diajarkan, satu diantaranya adalah Model Pembelajaran Kooperatif Tipe Jigsaw.

\section{DAFTAR PUSTAKA}

Arikunto, S. (2012). Dasar-dasar Evaluasi Pendidikan. Jakarta: Bumi Aksara.

Ausebel, D. P. (2000). The Acquisition and Retention of Knowledge: A Cognitive View. Netherlands: Springer-Science+Business Media, B.V. [Online]. Tersedia: http:www.springer.com/la/book/9780792365051

Depdiknas. (2006). Standar Kompempetensi Mata Pelajaran Matematika. Jakarta: Depdiknas. Hamdani. (2011). Strategi Belajar Mengajar. Bandung: Pustaka Setia.

Herawati, O.D.P. (2010). Pengaruh Pembelajaran Problem Posing Terhadap Kemampuan Pemahaman Konsep Matematika Siswa Kelas XI IPA SMA 6 Negeri Palembang. [Online]. Tersedia: http://ejournal.unsri.ac.id/index.php/jpm/view/312. [6 Oktober 2017].

Hudojo, H. (2003). Pengembagan Kurikulum dan Pembelajaran Matematika. Malang: JICA.

Imayati. (2013). Pengaruh Penerapan Model Pembelajaran Kooperatif Tipe Jigsaw terhadap Kemampuan Pemahaman Konsep Matematika Siswa Kelas VIII SMP Negeri 2 Kampar. 
178 AKSIOMA, Volume 8 Nomor 2, September 2019

Skripsi Sarjana pada FTK Universitas Islam Negeri Sultan Syarif Kasim Riau: tidak diterbitkan.

Indrawan, M. (2010). Perbedaan Antara Prestasi Belajar Matematika Menggunakan Model Pembelajaran Kooperatif Tipe Jigsaw dengan Pembelajaran Konvensional di MTsN Tulungagung Tahun Pelajaran 2009/2010. [Online]. Tersedia: http://repo.iaintulungagung.ac.id/1029 [6 Oktober 2017].

Isjoni. (2010). Cooperative Learning Efektivitas Pembelajaran Kelompok. Bandung: Penerbit Alfabeta.

Mulyasa, E. (2009). Analisis, Validitas, Reliabilitas, dan Interpretasi Hasil Tes: Implementasi Kurikulum 2004. Bandung: PT Remaja Rosdakarya.

National Council of Teachers Mathematics. (2000). Principles and Standards for School Mathematics. Drive, Reston. VA: The National Council of Teachers Mathematics.

Nurhikmah, Sudarman dan Hasbi, M. (2015). Penerapan Pendekatan Keterampilan Proses untuk Meningkatkan Hasil Belajar Siswa Pada Materi Keliling Dan Luas Daerah Segitiga di Kelas VII SMPN 21 Palu. Jurnal Elektronik Pendidikan Matematika, Vol. 02 No. 04, Juni 2015.

Rosyidah, U. (2016). Pengaruh Model Pembelajaran Kooperatif Tipe Jigsaw Terhadap Hasil Belajar Matematika Siswa Kelas VIII SMP Negeri 6 Metro. Jurnal SAP Vol. 1 No. 2 Desember 2016. ISSN: 2527-967X.

Sanjaya, W. (2006). Strategi Pembelajaran. Jakarta: Kencana Prenada Media Grup.

Slameto. (2010). Belajar dan Faktor-faktor yang Mempengaruhinya. Jakarta: Rineka Cipta.

Sudjana. (2002). Metode Statistika. Bandung: Tarsito.

Sugiyono. (2010). Statistik Untuk Penelitian. Bandung: Alfabeta.

Vygotsky, L. (1978). Interaction Between Learning and Development. In Gauvin \& Cole (Eds.). Reading on the Development of Children. New York: Scientific American Books. pp. 34-40. 